\title{
Characterization of Pyroclastic Deposit from Three Different Areas within Foumbot Region (West-Cameroon): Comparative Studies of Their Effects as Pozzolanic Materials in Mortars and Cement Manufacture
}

\author{
Mahomed Aziz Mounjouohou1*, Amidou Moundi², Benjamin Ntieche3, Daouda Dawai', \\ Frédéric Michel ${ }^{4}$ \\ ${ }^{1}$ Department of Earth Sciences, University of Maroua, Maroua, Cameroon \\ ${ }^{2}$ Department of Earth Sciences, University of Yaoundé I, Yaounde, Cameroon \\ ${ }^{3}$ Higher Teacher Training College, Geology laboratory, University of Yaoundé I, Yaounde, Cameroon \\ ${ }^{4}$ Department of Architecture, Geology, Environment and Construction, University of Liege, Liege, Belgium \\ Email: *azizmounj@yahoo.fr
}

How to cite this paper: Mounjouohou, M. A., Moundi, A., Ntieche, B., Dawai, D., \& Michel, F. (2019). Characterization of Pyroclastic Deposit from Three Different Areas within Foumbot Region (West-Cameroon): Comparative Studies of Their Effects as Pozzolanic Materials in Mortars and Cement Manufacture. Journal of Geoscience and Environment Protection, 7, 195-209. https://doi.org/10.4236/gep.2019.711014

Received: September 30, 2019 Accepted: November 25, 2019 Published: November 28, 2019

Copyright $\odot 2019$ by author(s) and Scientific Research Publishing Inc. This work is licensed under the Creative Commons Attribution International License (CC BY 4.0).

http://creativecommons.org/licenses/by/4.0/

\section{(c) (i) Open Access}

\begin{abstract}
Pyroclastics which are known natural pozzolanic materials due to amorphous contents, are present in several areas of the Mbepit Massif in West Cameroon. In this work natural pozzolan from three zones namely Pouoloum, Njimbouot and Nkouonja were characterized. A comparative study was then developed to attest the effect of these pyroclastics as partial substitution in portland cement. The mixtures were made at different pozzolanic proportions $(00 \%, 10 \%, 15 \%, 25 \%$ and $35 \%)$ of substitution of the cement. The compressive and flexibility strength was carried out at 7,28 and 90 days on mortar specimens $\left(4 \times 4 \times 16 \mathrm{~cm}^{3}\right)$. The results revealed apozzolanicactivity index of $81.99 \%, 83.47 \%$ and $74.54 \%$ respectively for rock sample from Pouoloum (PCB), sample from Njimbouot (PCC) and sample from Nkouonja (PCN). After 90 days, for a substitution rate of $25 \%$ compressive strength are respectively 55.69 MPa, 60.4 MPa, 53.34 MPa for PCB, PCC and PCN. According to the American Society for Testing and Materials (ASTM) C618 classification, the pyroclastics are in accordance with all the criteria to be classified as pozzolan. Independent of the substitution rate, the mechanical performance increases with age in PCB, PCC and PCN. However PCC is most reactive than PCB and PCN. This may be due to the amorphous reactive content in this material and can be linked to the eruptive dynamisms which were more explosive in some areas than in others. The amorphous content is $32.01 \%$,
\end{abstract}


36.99\%, 24.84\% for PCB, PCC and PCN respectively. These results also prove that Natural Pozzolan is interesting in the manufacture of composite cement CEM II, CEM IV in accordance with EN197-1 or can be added in mortar for buildings and sustainable environmental management.

\section{Keywords}

Pyroclastics, Pozzolanic Activity, Compressive Strength, Composite Cement, Natural Pozzolan, Mbepit Massif

\section{Introduction}

Pozzolans are a broad class of siliceous or siliceous and aluminous materials which, in themselves, possess little or no cementitious value but which will, in finely divided form and in the presence of water, react chemically with calcium hydroxide at ordinary temperature to form compounds possessing cementitious properties (Mehta, 1987). The quantification of the capacity of a pozzolan to react with calcium hydroxide and water is given by measuring its pozzolanic activity (Snellings et al., 2012). Pyroclastic rocks are blocks of solidified lava ejected during the eruption of a volcano and are classified as ashes, lapilli, bombs and blocks depending on their diameter (Heiken \& Wohletz, 1985). The samples were collected in the three different areas because pozzolan coming from different areas may not necessarily react in the same manner. Also, there are some variations in grain size in the different pozzolans in these three areas.

The Mbepit massif in the Noun Division (Figure 1) contains huge volcanic deposits of ash (diameter $<2 \mathrm{~mm}$ ) and lapilli $(2 \mathrm{~mm}>$ diameter $>64 \mathrm{~mm}$ ), exploitable as pozzolanic materials, for mixtures in mortars and manufactures of cements. The pozzolan of Foumbot area comes from the volcanic activities. Those activities have resulted in materials with different textures and structures according to the specific condition of the emission of lava and eruptive styles. Studies reveal that pozzolanic activity of materials from different areas may not

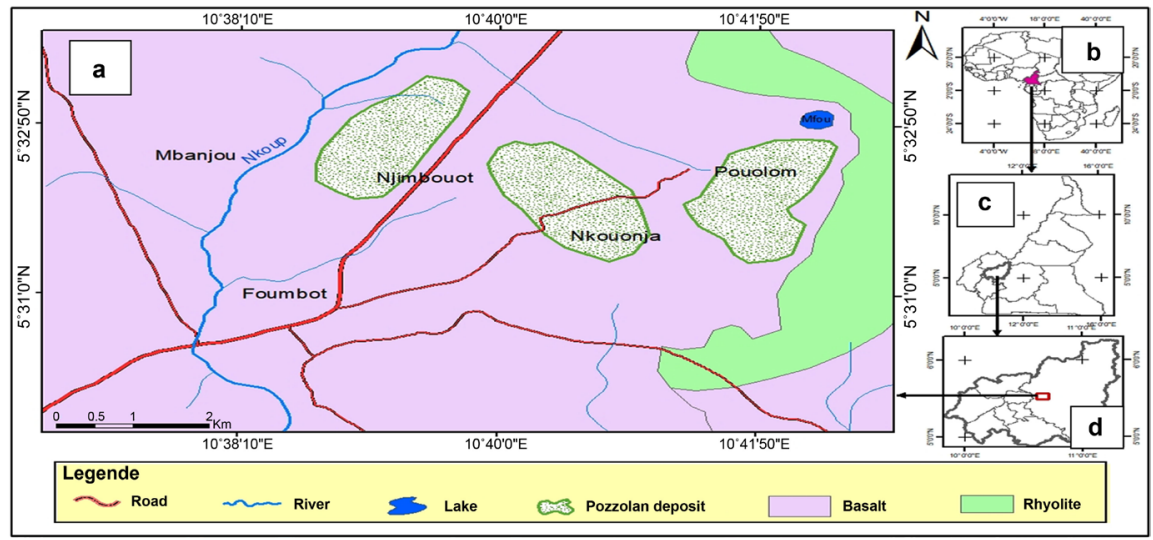

Figure 1. Geological map (a) showing the location of Cameroon (b); the location of Noun Division (c) and location of the study area (d). 
be the same and some parameters influencing the pozzolanic reactions include the nature of the active phases and their proportions in $\mathrm{SiO}_{2}$ content. The pozzolan of Foumbot area in the Noun Division comes from several episodic volcanic activities and dynamisms (effusive and explosive). These phenomenons prevent the total crystallization of minerals and promote the formation of amorphous and glasses, responsible for pozzolanic activity when they are combined with calcium hydroxide $\left(\mathrm{Ca}(\mathrm{OH})_{2}\right)$.

The natural pozzolans used as binder helps to protect the environment by reducing the consumption of portland cements. This also aids in reducing environmental pollution due to the manufacture of portland cement by partial substitution of clinker in portland cement with pozzolanic materials such as natural pozzolan (Mokhtaria et al., 2009), metakaolin, industrial waste such as silica fume, fly ash (Ayrinhac, 2005; Hosseini et al., 2011), blast furnace slag (Elke, 2012) and coal bottom ash (Cheriaf et al., 1999; Haldun \& Mine, 2007). The pozzolanic materials will contribute to the improvement of the mechanical properties of concretes due to the development of pozzolanic activity and the formation of second-generation calcium silicate hydrates CSH II (Cheriaf et al., 1999; Haldun \& Mine, 2007). The manufacture of portland cement produces very large quantities of $\mathrm{CO}_{2}$ during the decarbonation of $\mathrm{CaCO}_{3}$. The cement industry emits $5 \%$ to $7 \%$ of the global $\mathrm{CO}_{2}$ rate emitted into the atmosphere, with 0.9 tons of $\mathrm{CO}_{2}$ emitted during the manufacture of one ton of cement (Emad et al., 2013). The responsiveness of a pozzolanic material depends on several parameters and its reactivity varies from one pozzolan to another. This work will help 1) appreciate the mechanical resistance of mortars containing natural pozzolan from the Foumbot area and 2) to compare the pozzolanicity of pyroclastic material from three different sites (Figure 1) and 3) to appreciate their use in cement manufacture.

\section{Materials and Methods}

In this area, the basement of recent volcanic lavas is made up of gneiss and granite. The volcanic rocks are made up of basalts, rhyolites and colossal quantities of pyroclastic materials deposited in different areas (Tchokona, 2010).

\subsection{Materials}

Natural pozzolans were collected in three different areas, namely Pouoloum, Njimbouot and Nkouonja and the samples pseudo named as PCB, PCC and PCN respectively (Figure 2). The pozzolanic effect depends on the fineness of the particles (Isaia et al., 2003) suggesting grinding as the most appropriate treatment method in the study of natural pozzolan. The duration of grinding and different sieving aided approximatively the same granulometry in the three pozzolans after grinding. Moreover, the parameters influencing the pozzolanic reactions are the nature of the active phases and their proportions, the $\mathrm{SiO}_{2}$ content, the lime/pozzolan ratio in the mixture, the duration of the cure, the fineness of the 

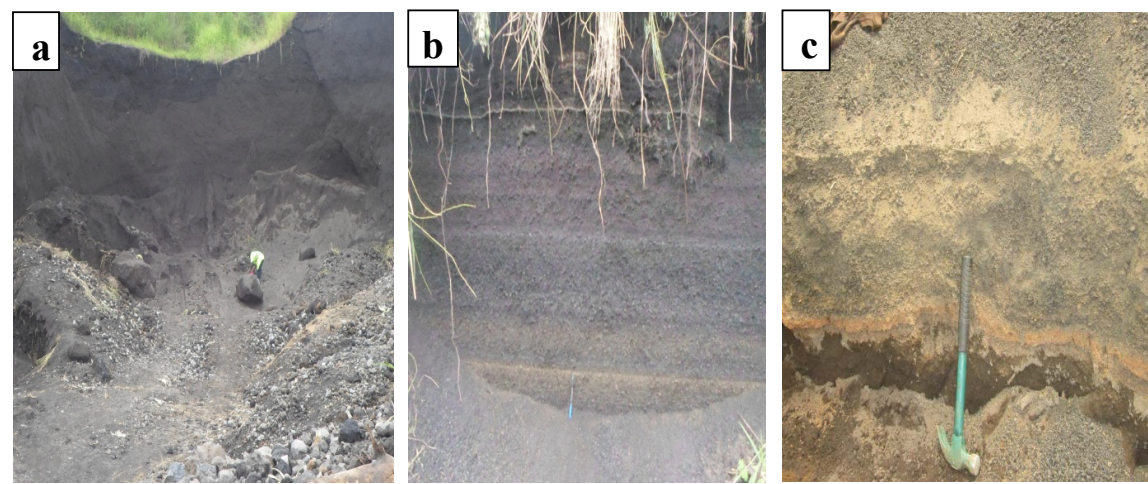

Figure 2. Natural pozzolan deposit in (a) Pouoloum site, (b) Njimbouot site and (c) Nkouonja site sampled for analysis.

pozzolan, the ratio $\mathrm{W} / \mathrm{C}$ of the mixture, the temperature, and the optimization of pozzolanicity (Shi, 2001). The mechanical performances are obtained due to the development of the pozzolanic activity. The sieving granulometry and the laser granulometry permitted to know the particle size distribution of the pozzolan particles both in the natural state and after grinding. The density measurement of pozzolan was made using the Pycnometer MultiVolume 1305 with gas, Brunauer-Emmett-Teller (BET) and the specific surface area using Micromeritics Instrument Corp. X-ray fluorescence reveals the composition of the major element composition of the pozzolan. Mineralogical phases content was done using $\mathrm{X}$ rays diffraction (XRD) method. The Keyser test permitted the estimation of the vitreous phase by the chemical method. This method consists in observing the dissolution kinetics of the amorphous sillico-aluminates in a $1 \%$ hydrofluoric acid solution in order to estimate the amorphous rate.

According to the American Society for Testing and Materials (ASTM) C618 (Standard ASTM standard, C618, 2008), a material is pozzolanic if:

- its chemical composition verified that $\mathrm{SiO}_{2}+\mathrm{Al}_{2} \mathrm{O}_{3}+\mathrm{Fe}_{2} \mathrm{O}_{3}>70 \%$;

- its glass content is such that $\left(\mathrm{SiO}_{2}-\mathrm{CaO}\right)>34$;

- its activity index for a substitution rate of $25 \%, \mathrm{I}_{25}$ at 28 days of cure verified that $67 \%<\mathrm{I}_{25}<100 \%$.

$$
I p=\left(R p / R_{0}\right) \times 100
$$

$R_{0}=$ compressive strength of the control mortar with $100 \%$ cement;

$p=25 \%$ of pozzolanic material;

$I=$ pozzolanic activity index;

$R_{p}=$ compressive strength of mortar with $p \%$ of pozzolan replacement by weight in cement.

\subsection{Methods}

\subsubsection{Mixtures and Tests}

Mixtures were made using water, sand, portland cement 52.5 with different mass substitution rate of cement by natural pozzolans. The mortars were molded into bars $\left(4 \times 4 \times 16 \mathrm{~cm}^{3}\right)$. They were demolded after 24 hours and then kept under 
water in favourable laboratory conditions. The compressive and flexural strength tests were carried out at 7, 28, and 90 days according to the European Standard methods of testing cement determination of strength (EN 196-1) (Standard EN 196-1, 2006).

\subsubsection{Estimation of the Vitreous Phase by the Keyser Method}

The standard Keyser method was done using $1 \%$ hydrofluoric acid solution for the dissolution of the amorphous silico-aluminates. $1 \mathrm{~g}$ of pozzolanic material was introduced into $200 \mathrm{ml}$ of $1 \%$ hydrofluoric acid solution and the solution was kept for 40 minutes and then filtered on an ashless filter paper. The residue was oven-dried at $105^{\circ} \mathrm{C}$ for 24 hours. The amorphous phase of the material was given by the formula below:

$$
\% \text { amorphous }=\left(m_{1}-m_{2}\right) / m_{1}
$$

$m_{1}=$ mass of material before dissolution;

$m_{2}=$ mass of the material after dissolution.

\section{Results and Discussions}

According to Table 1, the pozzolans of Foumbot area are basic in nature with $\mathrm{SiO}_{2}$ concentrations less than $50.88 \%$. These natural pozzolan contains iron, oxide, and aluminum oxide with a calcium oxide content less than $8.37 \%$. The loss on ignition (LOI) of the different samples is below 3 testifying the freshness of the pozzolanic materials. The $\mathrm{K}_{2} \mathrm{O} / \mathrm{Na}_{2} \mathrm{O}$ is below 1 showing that the pozolanic materials are mostly sodic. PCC sample has less content of $\mathrm{CaO}$. The XRD results (Figures 3(a)-(c)) show that all those pozzolans contain an amorphous phase. Pozzolan of our study area contains plagioclases, feldspars and pyroxenes and very low quartz content. This may testify the basic nature of the pyroclastics. The cement used is rich in $\mathrm{CaO}$ and $\mathrm{SiO}_{2}$ (Table 2).

Table 1. XRF analysis of PCB, PCC, PCN.

\begin{tabular}{ccccccccccccccc}
\hline $\begin{array}{c}\text { Chemical } \\
\text { composition }\end{array}$ & $\mathrm{SiO}_{2}$ & $\mathrm{TiO}_{2}$ & $\mathrm{Al}_{2} \mathrm{O}_{3}$ & $\mathrm{Fe}_{2} \mathrm{O}_{3}$ & $\mathrm{MnO}$ & $\mathrm{MgO}$ & $\mathrm{CaO}$ & $\mathrm{Na}_{2} \mathrm{O}$ & $\mathrm{K}_{2} \mathrm{O}_{2}$ & $\mathrm{P}_{2} \mathrm{O}_{5}$ & $\mathrm{LOI}$ & Sum \\
\hline $\begin{array}{c}\text { Pozzolan } \\
(\mathrm{PCB})\end{array}$ & 50.88 & 2.51 & 15.25 & 11.52 & 0.2 & 4.63 & 7.97 & 3.35 & 2.96 & 0.57 & 0.4 & 100.24 \\
$\begin{array}{c}\text { Pozzolan } \\
(\mathrm{PCC})\end{array}$ & 46.17 & 2.57 & 15.12 & 12.03 & 0.21 & 4.14 & 7.51 & 3.35 & 2.08 & 0.63 & 2.79 & 96.59 \\
$\begin{array}{c}\text { Pozzolan } \\
(\mathrm{PCN})\end{array}$ & 49.78 & 2.74 & 15.42 & 12.56 & 0.2 & 4.87 & 8.37 & 3.44 & 2.26 & 0.6 & 0.4 & 100.64 \\
\hline
\end{tabular}

Table 2. Chemical composition of cement.

\begin{tabular}{|c|c|c|c|c|c|c|c|c|c|c|c|c|}
\hline $\begin{array}{l}\text { Chemical and } \\
\text { mineralogy }\end{array}$ & $\mathrm{CaO}$ & $\mathrm{SiO}_{2}$ & $\mathrm{Al}_{2} \mathrm{O}_{3}$ & $\mathrm{Fe}_{2} \mathrm{O}_{3}$ & $\mathrm{C}_{2} \mathrm{~A}$ & $\mathrm{SO}_{2}$ & $\begin{array}{l}\text { Insoluble } \\
\text { residue }\end{array}$ & LOI & Chlorures & Chrome (VI) $^{+}$ & $\mathrm{Na}_{2} \mathrm{Oeq}^{++}$ & Sulfures \\
\hline $\begin{array}{c}\text { average } \\
\text { composition }\end{array}$ & 63.4 & 20.4 & 4.8 & 3.4 & 7.2 & 3.2 & 0.6 & 1.6 & 0.08 & 0.00012 & 0.74 & - \\
\hline Density & \multicolumn{12}{|c|}{$3100 \mathrm{Kg} / \mathrm{m}^{3}$} \\
\hline
\end{tabular}




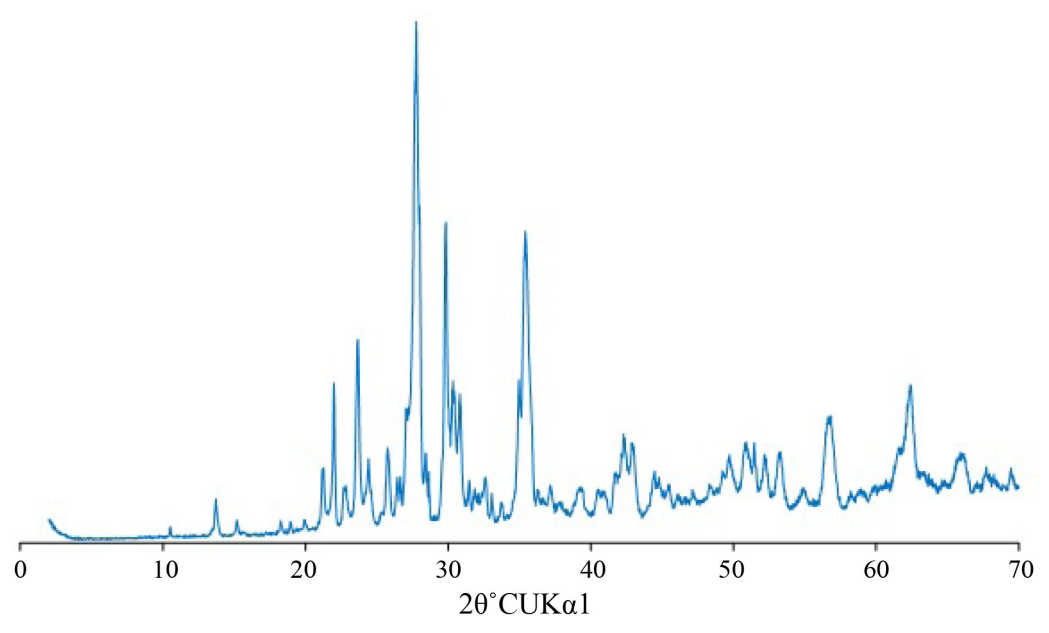

(a)

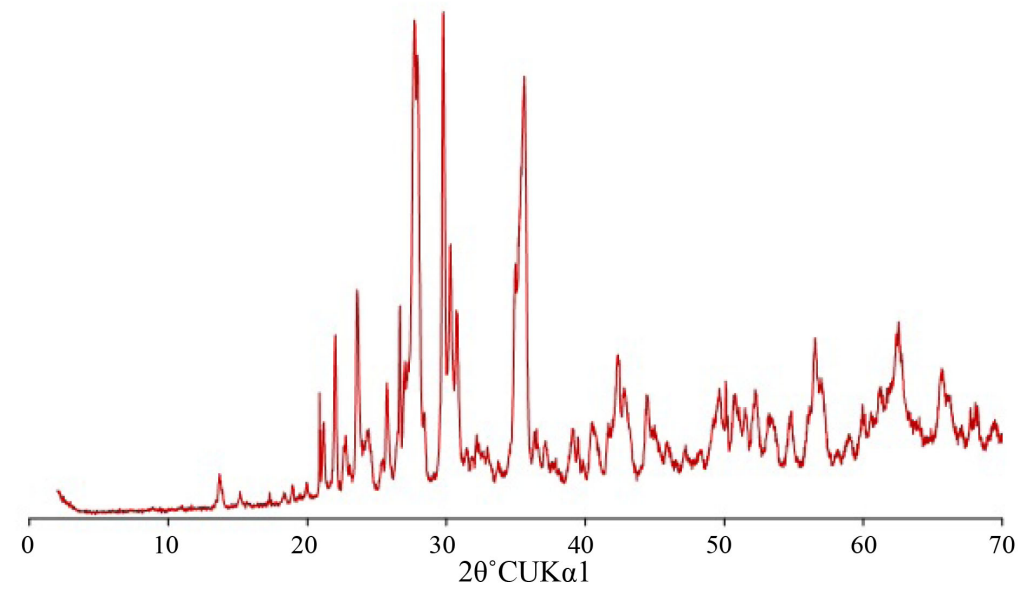

(b)

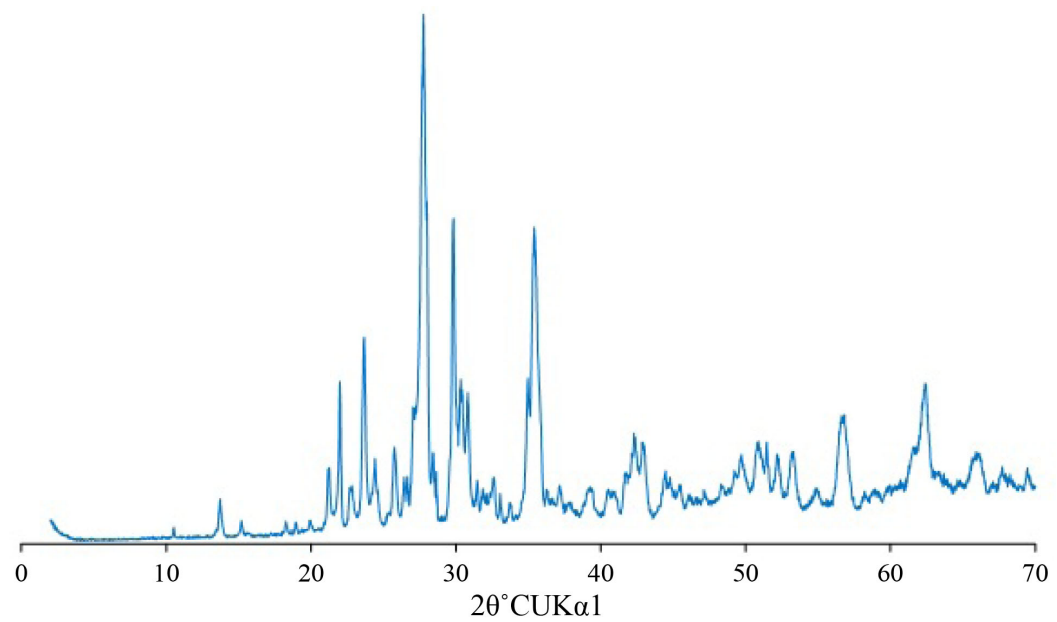

(c)

Figure 3. (a) X-ray fluorescence (XRD) of sample PCB; (b) XRD of sample PCN; (c) XRD of sample PCC. 


\subsection{Granulometric Results}

The granulometric results show that the natural pyroclastics are mostly made up of volcanic ashes i.e. less than $2 \mathrm{~mm}$ (Figure 4) and after grinding the average sizes were dominated by $10 \mu \mathrm{m}$ (Figure 5 ).

\subsection{Specific Surface Area}

The specific surface area of the pozolans is about $2.5 \mathrm{~m}^{2} / \mathrm{g}$ for the three samples after grinding.

\subsection{Keyser Results}

The obtained results show that the amorphous phase is higher in PCC with 36.99\% than PCB and PCN (Table 3(a)). These amorphous phases are responsible for the pozzolanic activities.

\subsection{Mixtures}

The table summarizes the various proportion of pozzolan that were successively utilized in the mixtures (Tables $3(\mathrm{~b})-(\mathrm{d})$ ).

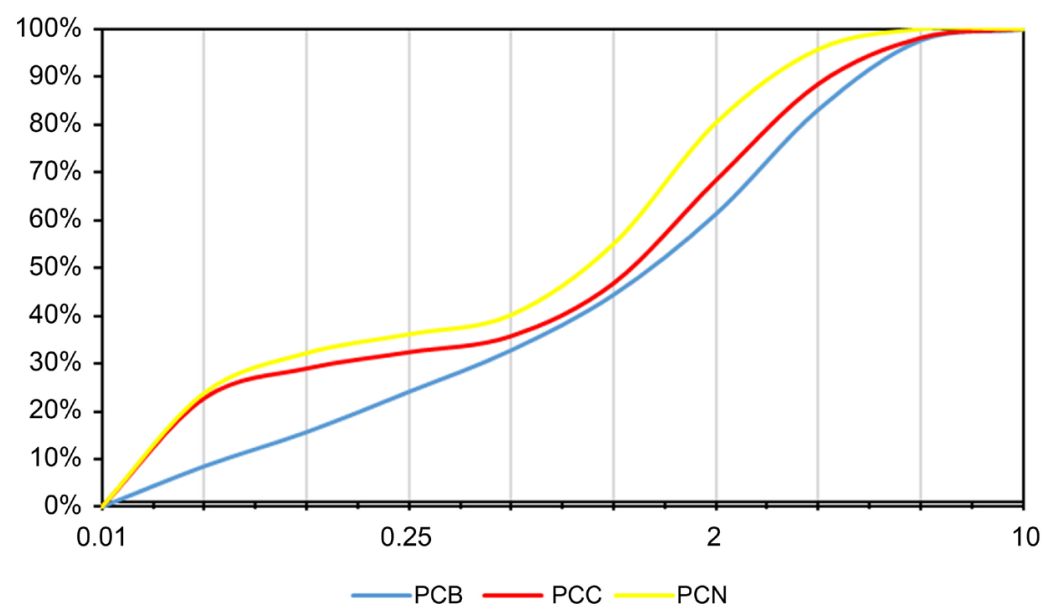

Diameter in $\mathrm{mm}$

Figure 4. Particle size distribution of natural pozzolan.

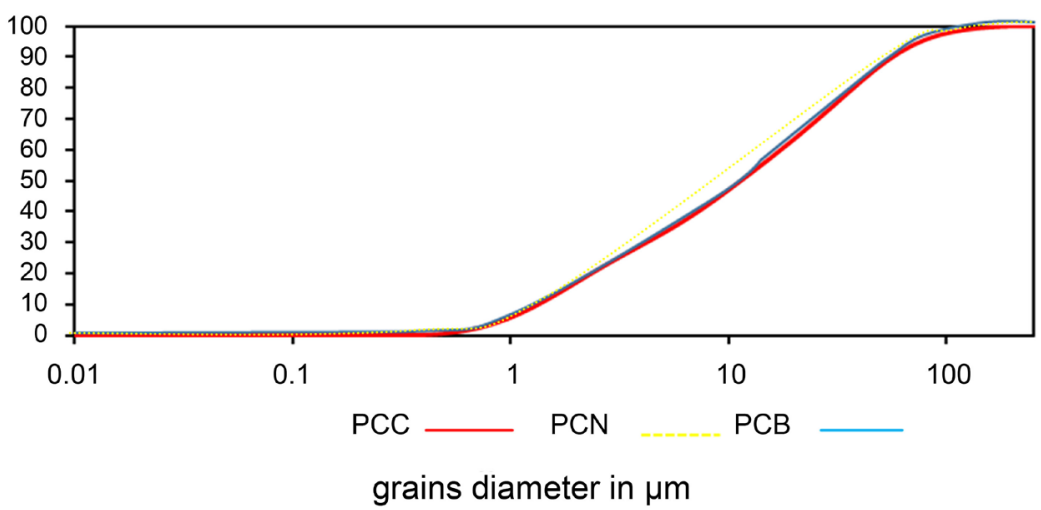

Figure 5. Particle size distribution of grinding pozzolan. 
Table 3. (a) Results from Keyser test; (b) Mixture proportion for PCB; (c) Mixture Proportion for PCC; (d) Mixture proportion for PCN.

(a)

\begin{tabular}{cccc}
\hline & PCB & PCC & PCN \\
\hline Values & $m_{1}=1.0176$ & $m_{1}=1.0033$ & $m_{1}=1.0195$ \\
& $m_{2}=0.6919$ & $m_{2}=0.6322$ & $m_{2}=0.7663$ \\
Amorphous phases & $32.01 \%$ & $36.99 \%$ & $24.84 \%$ \\
\hline
\end{tabular}

(b)

\begin{tabular}{|c|c|c|c|c|c|c|c|}
\hline \multirow{2}{*}{$\begin{array}{c}\text { Mixture } \\
\text { proportions }\end{array}$} & \multirow{2}{*}{$\begin{array}{l}\text { Pozzolan } \\
\text { rate }\end{array}$} & \multirow{2}{*}{$\begin{array}{c}\text { Quantity } \\
\text { (g) }\end{array}$} & \multirow{2}{*}{$\begin{array}{c}\text { Substitution } \\
\text { cement }\end{array}$} & \multirow{2}{*}{$\begin{array}{c}\text { Quantity } \\
\text { (g) }\end{array}$} & \multirow{2}{*}{$w / c$} & \multirow{2}{*}{$\begin{array}{l}\text { Sand } \\
\text { (g) }\end{array}$} & \multirow{2}{*}{$\begin{array}{l}\text { water } \\
(\mathrm{ml})\end{array}$} \\
\hline & & & & & & & \\
\hline PCB-00 & $0 \%$ & 0 & $100 \%$ & 450 & 0.5 & 1350 & 225 \\
\hline PCB-10 & $10 \%$ & 45 & $90 \%$ & 405 & 0.5 & 1350 & 225 \\
\hline PCB-15 & $15 \%$ & 67.5 & $85 \%$ & 382.5 & 0.5 & 1350 & 225 \\
\hline PCB-25 & $25 \%$ & 90 & $80 \%$ & 360 & 0.5 & 1350 & 225 \\
\hline PCB-35 & $35 \%$ & 112.5 & $75 \%$ & 337.5 & 0.5 & 1350 & 225 \\
\hline
\end{tabular}

(c)

\begin{tabular}{|c|c|c|c|c|c|c|c|}
\hline Mixture & Pozzolan & Quantity & Substitution & Quantity & & Sand & water \\
\hline proportions & rate & (g) & cement & (g) & W/c & (g) & $(\mathrm{ml})$ \\
\hline PCC-00 & $0 \%$ & 0 & $100 \%$ & 450 & 0.5 & 1350 & 225 \\
\hline PCC-10 & $10 \%$ & 45 & $90 \%$ & 405 & 0.5 & 1350 & 225 \\
\hline PCC-15 & $15 \%$ & 67.5 & $85 \%$ & 382.5 & 0.5 & 1350 & 225 \\
\hline PCC-25 & $25 \%$ & 90 & $80 \%$ & 360 & 0.5 & 1350 & 225 \\
\hline PCC-35 & $35 \%$ & 112.5 & $75 \%$ & 337.5 & 0.5 & 1350 & 225 \\
\hline
\end{tabular}

(d)

\begin{tabular}{|c|c|c|c|c|c|c|c|}
\hline \multirow{2}{*}{$\begin{array}{c}\text { Mixture } \\
\text { proportions }\end{array}$} & \multirow{2}{*}{$\begin{array}{l}\text { Pozzolan } \\
\text { rate }\end{array}$} & \multirow{2}{*}{$\begin{array}{c}\text { Quantity } \\
\text { (g) }\end{array}$} & \multirow{2}{*}{$\begin{array}{c}\text { Substitution } \\
\text { cement }\end{array}$} & \multirow{2}{*}{$\frac{\text { Quantity }}{\text { (g) }}$} & \multirow{2}{*}{$w / c$} & \multirow{2}{*}{$\begin{array}{c}\text { Sand } \\
(\mathrm{g})\end{array}$} & \multirow{2}{*}{$\begin{array}{l}\text { water } \\
(\mathrm{ml})\end{array}$} \\
\hline & & & & & & & \\
\hline PCN-00 & $0 \%$ & 0 & $100 \%$ & 450 & 0.5 & 1350 & 225 \\
\hline PCN-10 & $10 \%$ & 45 & $90 \%$ & 405 & 0.5 & 1350 & 225 \\
\hline PCN-15 & $15 \%$ & 67.5 & $85 \%$ & 382.5 & 0.5 & 1350 & 225 \\
\hline PCN-25 & $25 \%$ & 90 & $80 \%$ & 360 & 0.5 & 1350 & 225 \\
\hline PCN-35 & $35 \%$ & 112.5 & $75 \%$ & 337.5 & 0.5 & 1350 & 225 \\
\hline
\end{tabular}

Table 4. Compressive strengh results.

\begin{tabular}{cccccccccc}
\hline & \multicolumn{7}{c}{ Compressive strengh (Mpa) } \\
\cline { 2 - 10 } $\begin{array}{c}\text { Substitution rate } \\
\text { of pozzolan (\%) }\end{array}$ & \multicolumn{7}{c}{7 days } & \multicolumn{7}{c}{28 days } \\
\cline { 2 - 11 } & PCB & PCC & PCN & PCB & PCC & PCN & PCB & PCC & PCN \\
\hline 0 & 52.02 & 52.02 & 52.02 & 65.05 & 65.05 & 65.05 & 67.02 & 67.02 & 67.02 \\
10 & 49.8 & 50.1 & 47.8 & 59.03 & 63.2 & 57.06 & 62.94 & 66.03 & 59.8 \\
15 & 48.09 & 49.5 & 44.9 & 56.94 & 58.5 & 52.43 & 58.96 & 62.83 & 56.06 \\
25 & 39.05 & 43.6 & 37.05 & 53.34 & 54.3 & 48.49 & 55.69 & 60.4 & 53.34 \\
35 & 36.6 & 40.5 & 35.08 & 44.59 & 50.96 & 42.6 & 50.15 & 52.3 & 46.31 \\
\hline
\end{tabular}


Table 5. Flexural strength development results.

\begin{tabular}{|c|c|c|c|c|c|c|c|c|c|}
\hline \multirow{3}{*}{$\begin{array}{l}\text { Substitution rate } \\
\text { of pozzolan }\end{array}$} & \multicolumn{9}{|c|}{ Flexural strengh (Mpa) } \\
\hline & \multicolumn{3}{|c|}{7 days } & \multicolumn{3}{|c|}{28 days } & \multicolumn{3}{|c|}{90 days } \\
\hline & PCB & PCC & PCN & PCB & PCC & PCN & РCB & PCC & PCN \\
\hline 0 & 8.8 & 8.8 & 8.8 & 10.08 & 10.08 & 10.08 & 10.98 & 10.98 & 10.98 \\
\hline 10 & 7.58 & 8.6 & 7.1 & 8.98 & 9.56 & 8.55 & 9.25 & 10.01 & 8.9 \\
\hline 15 & 7.01 & 8.1 & 6.7 & 8.02 & 9.22 & 7.91 & 9.02 & 9.99 & 8.2 \\
\hline 25 & 6.5 & 7.41 & 6.3 & 7.38 & 8.64 & 7.08 & 8.69 & 9.56 & 7.89 \\
\hline 35 & 6.01 & 6.9 & 6.1 & 7.09 & 8.32 & 6.96 & 8.12 & 9.09 & 7.11 \\
\hline
\end{tabular}

The results in Figures 6(a)-(d) and Figures 7(a)-(d) show that the compressive and flexural strength decrease with the increase of the substitution rate of pozzolan. The compressive and the flexural strength are low at 7 and 28 days in mortar containing pozzolan. But at old age (90 days) the mortar having $10 \%$ of pozzolan has greater compressive values $62.94 \mathrm{Mpa}$, 66.03 Mpa, 59.8 Mpa respectively for $\mathrm{PCB}, \mathrm{PCC}$ and $\mathrm{PCN}$, closer to the reference mortar which has a value of $67.02 \mathrm{MPa}$ at the same age. This is because at a young age (before 28 days) many pozzolan ash particles remained unattacked by calcium hydroxides as it is the case in coal bottom ash particle and in rice husk ash (Hwang et al., 2011). Mortars made from pozzolan, despite their poor performance at a young age tend to catch up with time the reference mortar at 90 days (Table 4 and Table 5).

\subsection{Pozzolanic Index Activity}

The results reveal that for the three study pyroclastics, the pozzolanic activity index is greater or equal to $74.54 \%$ (Table 6).

According to Figure 8, the activity index values decrease with the increase of pozzolan content. The 03 pozzolans $\mathrm{PCB}, \mathrm{PCC}$ and PCN activity indexes are $82 \%, 83.47 \%$ and $74.54 \%$ respectively. This shows that PCC is the most reactive pozzolan followed by PCB and PCN.

According to ASTM Standard C 618 standard the pyroclastic materials (volcanic ashes and lapilli) of the study area are pozzolans. The results show that at a young age (28 days), the compressive strength decreases with the increase of the pozzolan substitution rate. This would be due to the low power consumption of lime $\mathrm{Ca}(\mathrm{OH})_{2}$ by pozzolan at this age. At $10 \%$ of substitution rate, PCC sample compressive strength is $66.03 \mathrm{MPa}$ closer to the reference moctar value of 67.02 $\mathrm{MPa}$ at 90 days compared to PCB (62.94 MPa) and PCN (59.8 MPa) (Table 7). Up to $35 \%$ of pozzolan substitution rate, the value of PCC $(52.3 \mathrm{MPa})$ is greater than those of PCB (50.15) and PCN (46.31) at 90 days. No matter the substitution rates, the compressive strength of PCC, PCB, PCN increase with age. This is due to the pozzolanic activity of those pyroclastic materials which allow them to consume lime $\mathrm{Ca}(\mathrm{OH})_{2}$ and $\mathrm{CH}$ and densify voids and pores in the mortar. This justifies the increase of compressive strength with age of the mortars. The hydration products fill the capillary pores and increase the resistance by refining these capillary pores and by transforming the large crystals of $\mathrm{CH}$ into $\mathrm{CSH}$. 


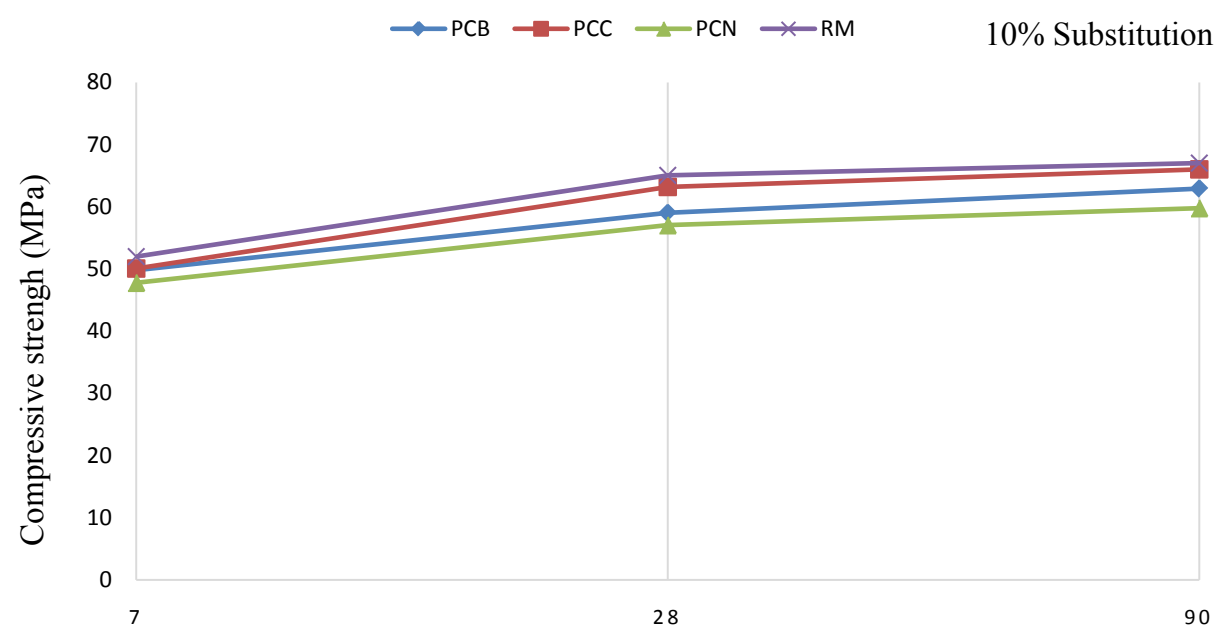

Age in days

(a)

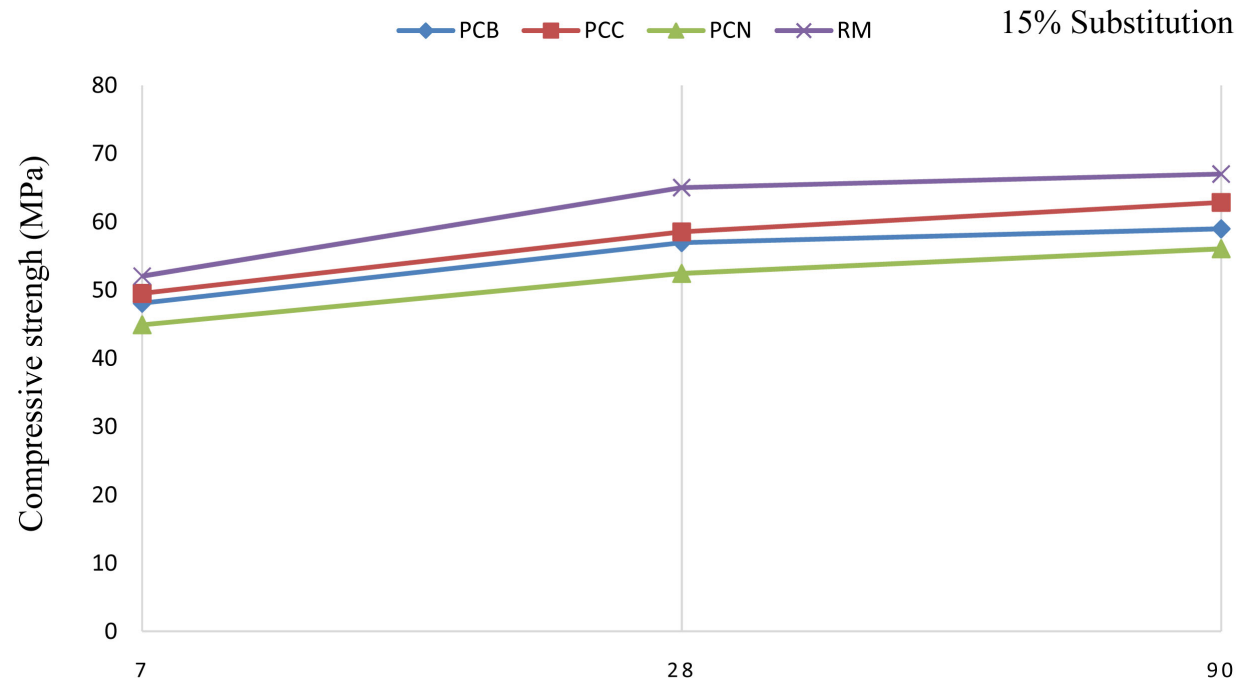

Age in days

(b)
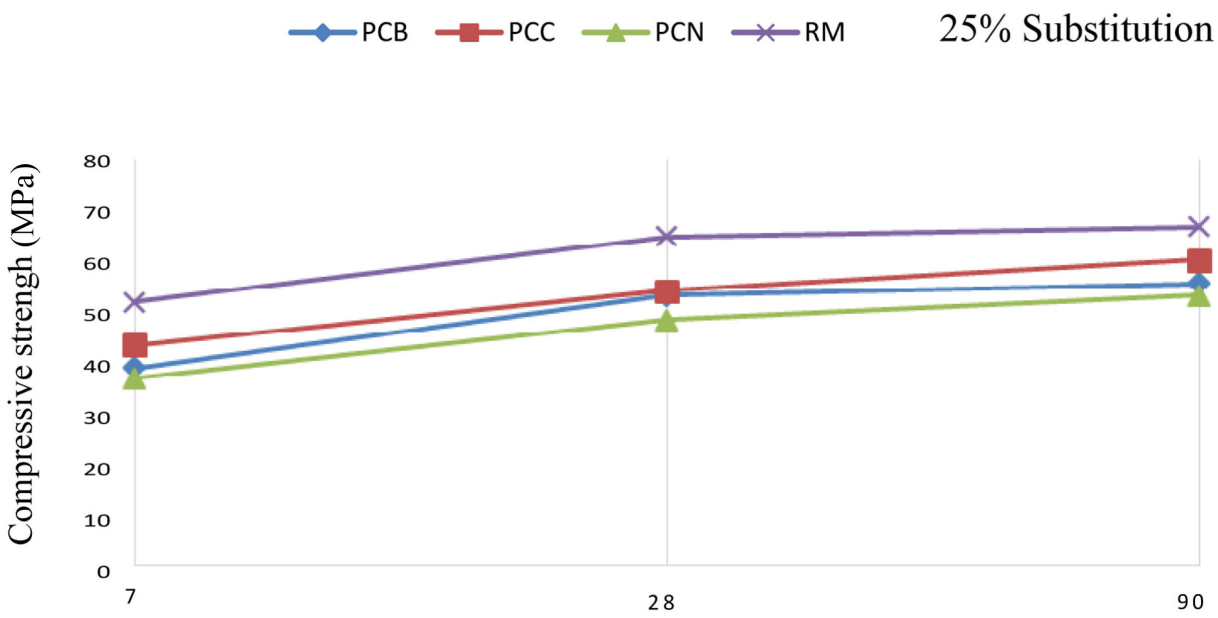

(c) 


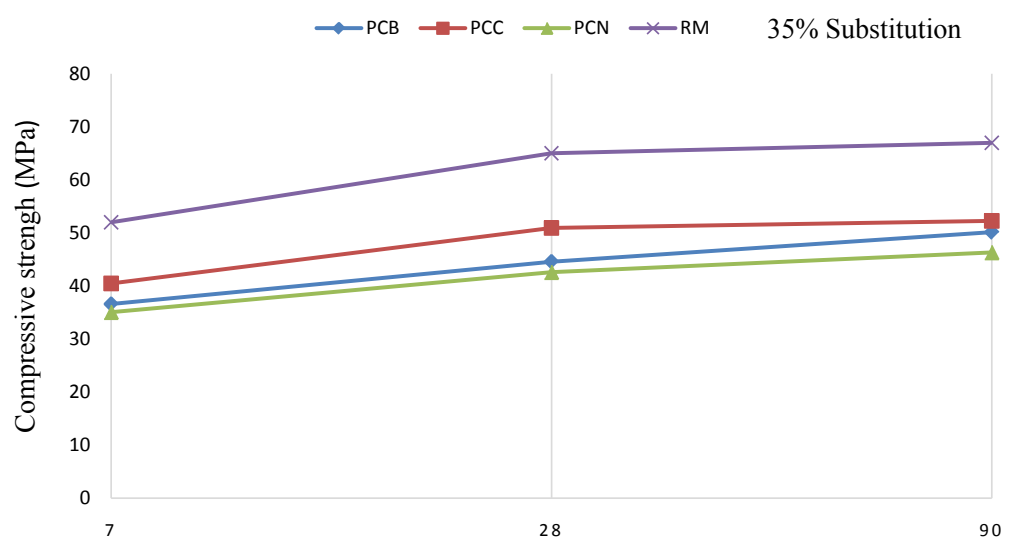

Age in days

(d)

Figure 6. (a) Compressive strength development at 10\% substitution rate; (b) compressive strength development at $15 \%$ substitution rate; (c) compressive strength development at $25 \%$ substitution rate; (d) compressive strength development at $35 \%$ substitution rate.

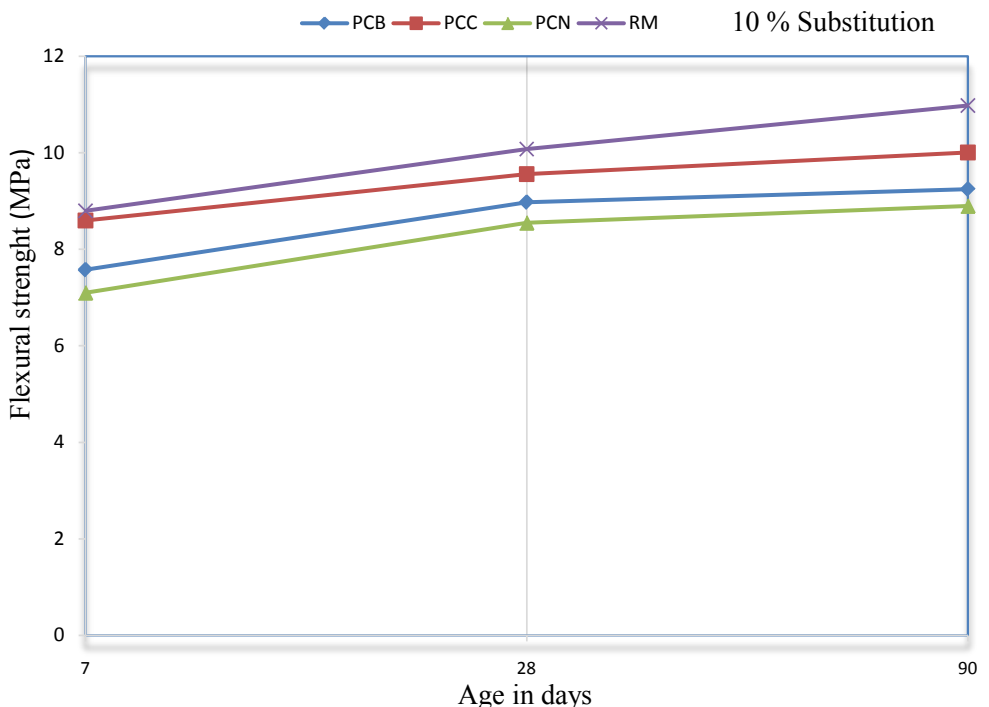

(a)

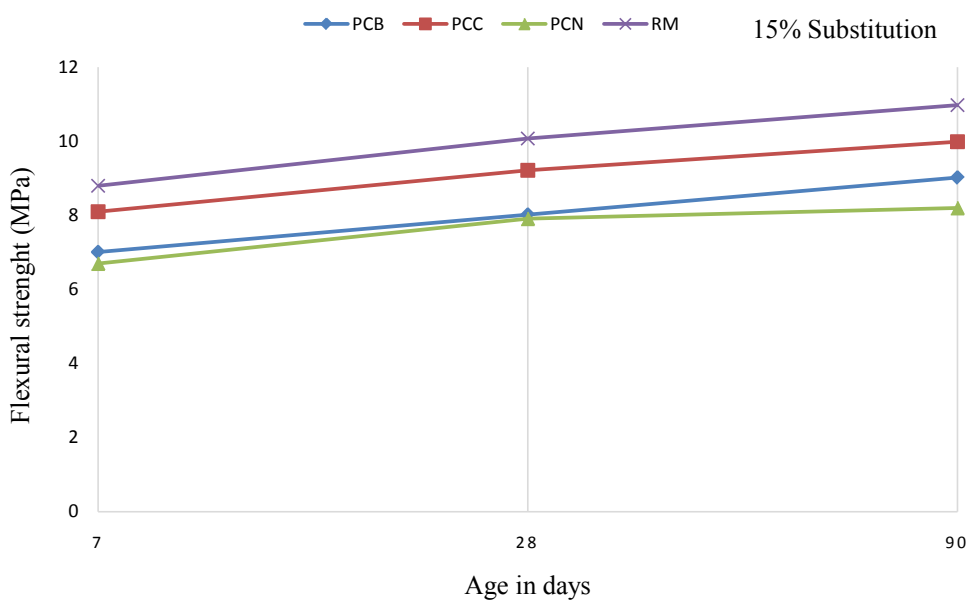

(b) 


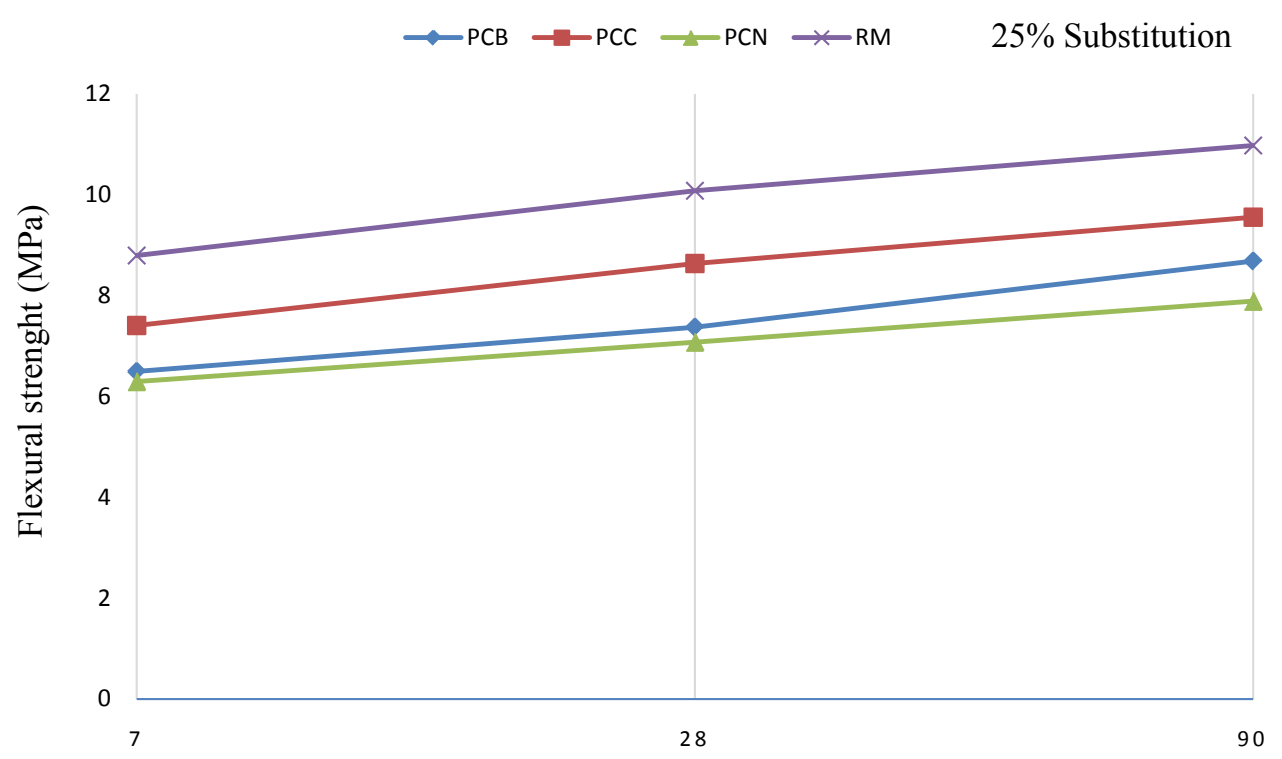

Age in days

(c)

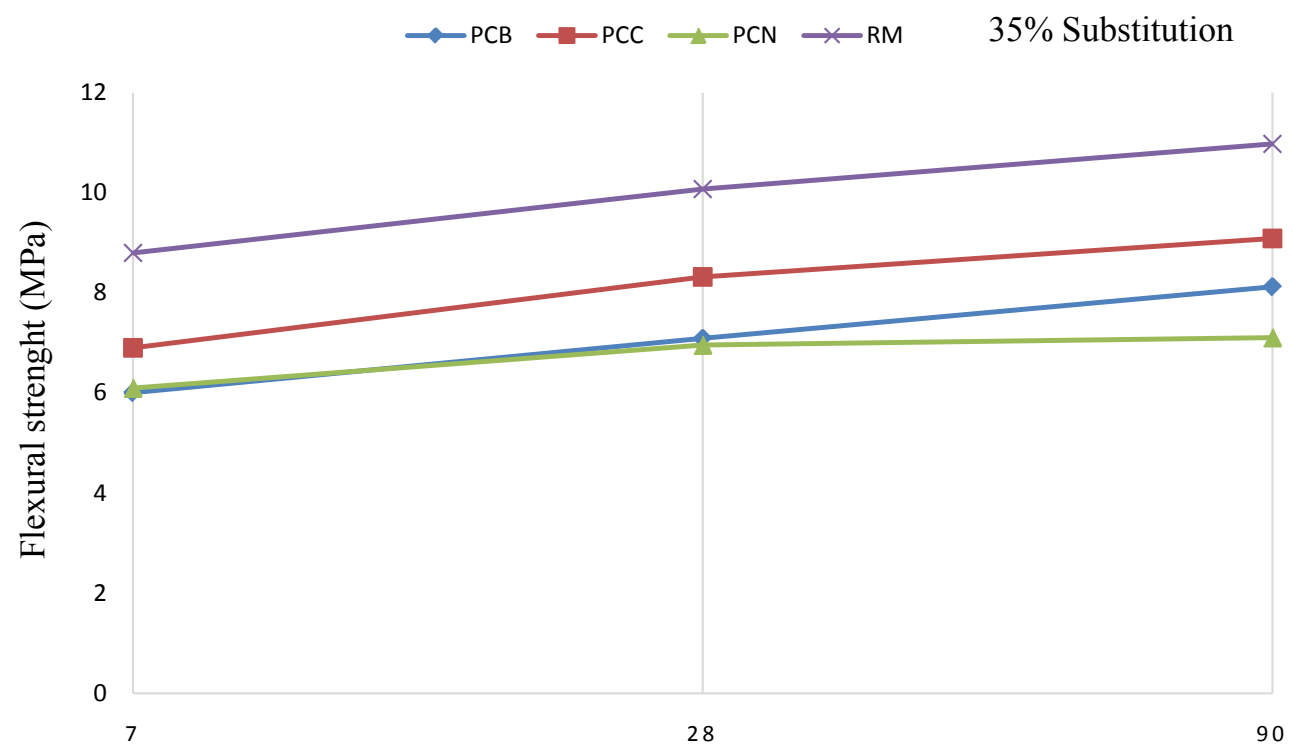

Age in days

(d)

Figure 7. (a) Effect of pozzolan on flexural strength at $10 \%$ substitution rate; (b) effect of pozzolan on flexural strength at $15 \%$ substitution rate; (c) effect of pozzolan on flexural strength at $25 \%$ substitution rate; (d) effect of pozzolan on flexural strength at $35 \%$ substitution rate.

Table 6. Activity index development.

\begin{tabular}{cccc}
\hline Mixture N $^{\circ}$ & Substitution rate & Compressive strength at 28 days & Reactivity index \\
\hline PCB & $25 \%$ & 53.34 & $81.99 \%$ \\
PCC & $25 \%$ & 54.3 & $83.47 \%$ \\
PCN & $25 \%$ & 48.49 & $74.54 \%$ \\
\hline
\end{tabular}




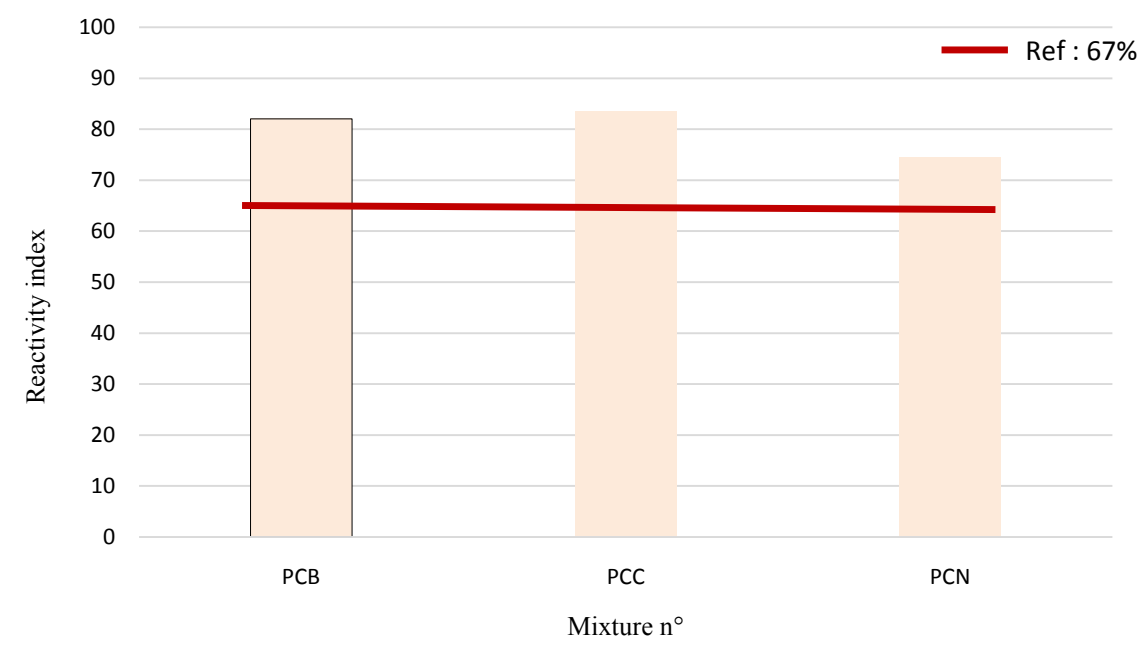

Figure 8. Activity index of pozzolan.

Table 7. ASTM parameters of pozzolan samples.

\begin{tabular}{cccc}
\hline Parameter & PCB & PCC & PCN \\
\hline $\mathrm{Al}_{2} \mathrm{O}_{3}+\mathrm{SiO}_{2}+\mathrm{Fe}_{2} \mathrm{O}_{3}$ & 77.65 & 73.32 & 77.76 \\
$\mathrm{SiO}_{2}-\mathrm{CaO}$ & 42.91 & 38.66 & 41.41 \\
$\mathrm{IR}$ & $81.99 \%$ & $83.47 \%$ & $74.54 \%$ \\
\hline
\end{tabular}

$$
\mathrm{SiO}_{2}+\mathrm{CH}+\mathrm{H}_{2} \mathrm{O} \rightarrow \mathrm{Cx}^{\prime} \mathrm{SHy}^{\prime}+(2-x) \mathrm{CH}
$$

The results also show that the pozzolans of the area are interesting to manufacture composite cement CEM II and CEM IV A in accordance with EN197-1 (Standard NF EN 197-1, 2001) or to add it in mortar for buildings and sustainable environmental management. Using a CEM I 52.5 with $10 \%$ substitution by pozzolans, the compressive strength values are 59.03 $\mathrm{MPa}, 63.2 \mathrm{MPa}, 57.06 \mathrm{MPa}$ for PCB, PCC and PCN respectively at 28 days. This result shows that it is possible to manufacture composite cement CEMII using PCB, PCC and PCN pyroclastites as natural pozzolan. At 15\% substitution, PCB (56.94 MPa) and PCC (58.5 $\mathrm{MPa}$ ) fulfill the criteria to manufacture a composite cement CEM II but not PCN (52.43 MPa). At 25\% substitution rate, it is possible to use $\mathrm{PCB}$ and PCC to manufacture pozzolanic cement CEM IV A with regard to the values of 53.34 MPa and 54.3 MPa repectectively obtained for PCB and PCC at 28 days. At this age, $\mathrm{PCN}$ has a value of 48.49 which is under $52.5 \mathrm{MPa}$. However, it may be possible to use PCN in order to manufacture a cement CEM IV 42.5 or 32.5 from a CEM I 52.5.

\section{Conclusion}

The results of the study reveal that the three pyroclastic materials are pozzolans according to the American ASTM C 618 classification, with the sum of major elements $\mathrm{Al}_{2} \mathrm{O}_{3}+\mathrm{SiO}_{2}+\mathrm{Fe}_{2} \mathrm{O}_{3}>70 \%$, the activity index at 28 days $\mathrm{I}_{25}>67 \%$ and the difference of major elements $\left(\mathrm{SiO}_{2}-\mathrm{CaO}\right)>34$. At 90 days, mortars having 
$10 \%$ of pozzolan have better compressive and flexural strengths closer to the reference mortar. The results reveal that it is possible to manufacture composite cements CEMII and CEMIV using the Foumbot pyroclastics as natural pozzolan and that mortar mixtures with pozzolan will portray good mechanical properties at 90 days. Pozzolan PCC from Njimbouot is more reactive than the others and is expected to be best suited for cement manufacture. Composite cements manufactured from these rocks are environmentally sustainable as they will emit low $\mathrm{CO}_{2}$ and is highly economically viable as the process requires less energy compare to Portland cement. The low production cost and the environment-friendly nature of the composite cement provide an affordable option for the construction industry.

\section{Acknowledgements}

We thank the "Académie de Recherche et d'Enseignement Supérieur (ARES)" grants program that financed my travel, tests and analyses at the construction and building materials laboratory of the University of Liège, Belgium.

\section{Conflicts of Interest}

The authors declare no conflicts of interest regarding the publication of this paper.

\section{References}

Ayrinhac, F. (2005). Valorisation des cendres volantes de chaudière à lit fluidisé circulant dans la filière du génie civil. PhD Thesis, INSA deToulouse, 180.

Cheriaf, M., Cavalcante, J., \& Pera, R. J. (1999). Pozzolanic Properties of Pulverized Coal Combustion Bottom Ash. Cement and Concrete Research, 29, 1387-1391. https://doi.org/10.1016/S0008-8846(99)00098-8

Elke, G. (2012). Investigation of the Influence of Blast-Furnace Slag on the Resistance of Concrete against Organic Acid or Sulphate Attack by Means of Accelerated Degradation Tests. Cement and Concrete Research, 42, 173-185. https://doi.org/10.1016/j.cemconres.2011.09.009

Emad, B., Gholamreza, Z., Ezzatollah, S., \& Alireza, B. (2013). Global Strategies and Potentials to Curb $\mathrm{CO}_{2}$ Emissions in Cement Industry. Journal of Cleaner Production, 51, 142-161.

Haldun, K., \& Mine, K. (2007). Usage of Coal Combustion Bottom Ash in Concrete Mixture. Construction and Building Materials, 22, 1922-1928. https://doi.org/10.1016/j.conbuildmat.2007.07.008

Heiken, G., \& Wohletz, K., (1985). Volcanic Ash (pp. 246). Berkeley, CA: University of California Press.

Hosseini, M. M., Shao, Y., \& Whalen, J. K. (2011). Biocement Production from Silicon-Rich Plant Residues: Perspectives and Future Potential in Canada. Biosystems Engineering, 110, 351-362.

Hwang, C., Bui Le, A., \& Chenchun, T. (2011). Effect of Rice Husk Ash on the Strength and Durability Characteristics of Concrete. Construction and Building Materials, 25, 3768-3772. https://doi.org/10.1016/j.conbuildmat.2011.04.009 
Isaia, G., Gastaldini, A., \& Moraes, R. (2003). Physical and Pouzzolanic Action of Mineral Additions on the Mechanical Strength of High Performance Concrete. Cement and Concrete Composites, 25, 69-76. https://doi.org/10.1016/S0958-9465(01)00057-9

Mehta, P. K. (1987). Natural Pozzolans: Supplementary Cementing Materials in Concrete. CANMET Special Publication, 86, 1-33.

Mokhtaria, B., Fatiha, K. A., \& Abdelaziz, S. (2009). Durabilité des mortiers à base de pouzzolane naturelle et de pouzzolane artificielle. Revue Nature et Technologie, No. 1, 163-173.

Shi, C. (2001). An Overview on the Activation of Reactivity of Natural Pozzolans. Canadian Journal of Civil Engineering, 28, 778-786. https://doi.org/10.1139/101-041

Snellings, R., Mertens, G., \& Elsen J. (2012). Supplementary Cementitious Materials. Reviews in Mineralogy and Geochemistry, 74, 211-278.

https://doi.org/10.2138/rmg.2012.74.6

Standard ASTM standard, C618 (2008). Standard Specification for Coal Fly Ash and Raw or Calcined Natural Pozzolan for Use of a Natural Admixture in Concontre. Annual Book of ASTM Standards.

Standard EN 196-1 (2006). Méthode d'essais des ciments partie 1: Détermination des resistances mécaniques.

Standard NF EN 197-1 (2001). Ciment, spécifications et critères de conformité-partiel: Ciments courants.

Tchokona, S. D. (2010). Volcanisme Paléogène à Récent du secteur du massif de Mbepit (Plaine du Noun): Pétrologie, minéralogie, géochimie isotopique, géochronologie et approche environnementale. $\mathrm{PhD}$ Thesis, University of Yaoundé I, 156. 